\title{
A HISTÓRIA CONTADA NAS PÁGINAS DOS JORNAIS
}

Sonia Aparecida Lopes Benites*

\section{Apresentação}

$\mathbf{O}$

presente trabalho focaliza a produção da leitura do texto jornalístico, de forma a permitir reconhecer o funcionamento do discurso e a depreender, no extrato lingüístico-discursivo dos textos, a intencionalinalidade, quer venha ela implícita, sob forma de indícios verbais, quer se apresente de maneira mais explícita, definidora do posicionamento do autor do texto.

O "corpus" de análise, caderno "brasil" do jornal Folha de São Paulo, no período compreendido entre março e julho de 1991, focaliza um importante período da história recente do Brasil: o início da veiculação dos episódios que culminariam no impeachment do presidente Fernando Collor de Mello. Após um pequeno distanciamento temporal, é possível constatar que o Jornal, mais do que narrar e comentar os fatos, foi um dos responsáveis pelo desfecho que tiveram, o que evidencia o papel dos órgãos de imprensa como veículos de ação e influência, não apenas de informação.

* Universidade Estadual de Maringá 
Para a análise pretendida, mostra-se imprescindível a consideração de subsídios fornecidos pelo esclarecimento das imagens que o leitor e o jornal fazem um do outro, de si próprios e do referente, bem como a explicitação do contexto histórico-social em que se dá o discurso, e da ideologia subjacente ao periódico.

\section{A face pública do jornal}

\section{A Folha de São Paulo e sua auto-imagem}

As imagens que condicionam a produção dos textos jornalísticos aqui presentes foram depreendidas nas orientações de redação fornecidas pelo $M a$ nual de Redação da Folha de São Paulo, em peças publicitárias, que explicitam a auto-imagem do Jornal e delineiam sua posição ideológica, e em indicações contidas nos próprios textos do referido periódico.

Segundo o Novo Manual de Redação da Folha de São Paulo (NMr), publicado em 1992, a Folha pretende desenvolver: "um jornalismo crítico, apartidário e pluralista"(p. 13). Para mostrar a realidade do ponto de vista crítico, postula-se a comparação de fatos, o estabelecimento de analogias, a identificação de atitudes contraditórias e a veiculação de diferentes versões para um mesmo acontecimento. O NMR enfatiza que o jornalismo crítico não depende da opinião de quem escreve, sendo mais contundente o registro ou o confronto de dados, as informações e opiniões alheias (cf. verbete opinião). Nesse sentido, assenta-se que a opinião do jornalista não deve permear o texto noticioso, mas constar de texto à parte, geralmente assinado, e ser fundamentada e sustentada por fatos e dados concretos.

$\mathrm{O}$ apartidarismo e o pluralismo pregam o não atrelamento do Jornal a grupo, tendência ideológica, ou partido político (p. 8), e estabelecem que o Jornal deve negar-se a participar de campanhas para enaltecer ou desacreditar pessoas, e adotar uma posição clara face a toda questão controversa, além de publicar posições divergentes da sua.

Contribui para a complementação da auto-imagem do Jornal a afirmação do NMr de que a Folha de São Paulo é, desde os anos 80, "o diário de maior influência e circulação no Brasil" (p. 17), exercendo papel importante como formador de opinião e de hábitos. 
No que se refere ao ponto de vista político, o NMR afirma que $a$ Folha de São Paulo sustenta a democracia representativa, a economia de mercado, os direitos do homem e o debate dos problemas sociais colocados pelo subdesenvolvimento. (p.13)

Além de estar presente no NMR, a imagem que o Jornal tem de si e que deseja transmitir aos outros pode ser depreendida também a partir de campanhas publicitárias, desenvolvidas periodicamente, nas quais o desempenho da Folha de São Paulo é freqüentemente comparado ao do jornal Estado de São Paulo, este referido como concorrente, em termos de independência, circulação, capacidade de formação de opinião e vanguarda na informação.

Como exemplo do reflexo dessa imagem na propaganda, pode-se tomar uma peça publicitária de três páginas, veiculada em 13 de junho de 1993, com o "slogan" FOLHA. Não dá pra não ler. Como fundo da primeira página, há uma ilustração, representando uma multidão, e uma faixa onde se lê FORA COLLOR, palavra de ordem das passeatas pró-impeachment. A multidão também lembra a campanha pelas eleições diretas e as manifestações estudantis realizadas na década de setenta, fatos sobre os quais também se baseia a argumentação do texto. Sobre o fundo, são colocadas a posição da Folha e a do jornal concorrente perante quatro fatos importantes da política nacional contemporânea, de acordo com recortes textuais feitos pelo Jornal:

1977. A Folha apóia as manifestações estudantis. O concorrente fica de cara amarrada.

1983. A Folha entra com tudo na campanha pelas diretas-já. O concorrente sai pela tangente.

1989. Collor eleito. A Folha prevê 5 anos de dúvidas e obscuridades. O concorrente prevê o resgate da moralidade no poder. Setembro de 1991. A Folha pede o impeachment de Collor. O concorrente pede calma.

A segunda e a terceira páginas constituem um bloco que tem como título o "slogan" da propaganda: Folha. Não dá pra não ler. O texto que se segue ressalta os motivos pelos quais o Jornal seria sempre o primeiro a apresentar as informações: sua independência, que teria feito aumentar sua circulação e, conseqüentemente, seu poder como órgão formador de opinião. Apresenta também uma "promoção" do leitor, cuja opinião influenciaria o Jornal, 
possibilitando-lhe independência financeira e se constituindo, enfim, em um leitor que não dá pra não ter.

Observa-se, na auto-imagem do jornal em estudo, uma certa contradição, pois ele se vê, ao mesmo tempo, como um veículo apartidário, pluralista, de vanguarda, ágil e preciso na denúncia e na veiculação da informação. Mas, enquanto apartidarismo e pluralismo pressupõem um jornalismo não opinativo, vanguarda e denúncia supõem opinião clara, tomada de posição específica. Essa contradição já anuncia a tensão entre a pretendida objetividade do Jornal e o seu caráter opinativo.

\section{O Jornal visto por outros}

Se, atualmente, é possível identificar a diretriz ideológica que conduz o periódico em análise, nem sempre foi assim. Segundo Marcondes Filho (1986), diferentemente de $O$ Estado de São Paulo, seu principal concorrente, a Folha de São Paulo não tinha, até pouco tempo, uma identidade política definida.

$\mathrm{O}$ autor afirma que $O$ Estado de São Paulo sempre se posicionou como um jornal ideológico de envergadura, um veículo conservador, um porta-voz das elites que compuseram o empresariado paulista. Na visão de Marcondes Filho, por possuir compromissos de classe no quadro estadual, esse jornal tem primado, desde sua fundação, pela coerência com sua política liberal e com as posições de interesse das classes burguesas.

Já a Folha de São Paulo, periódico lido majoritariamente pelos diversos setores da classe média, segundo o mesmo autor, oscilou entre posições direitistas e esquerdistas. Teria chegado a ficar, por vezes, do mesmo lado de $O$ Estado de São Paulo como ao colocar-se contra o ex-presidente João Goulart e sua república sindicalista-populista. Em outros momentos, como no período da censura imposta à imprensa pelo governo Médici, enquanto outros veículos publicavam, nos espaços de matérias censuradas, receitas culinárias, versos de Camões, desenhos, arvorezinhas e faixas pretas, a Folha abstinha-se de protestar contra as arbitrariedades cometidas pelo governo.

Ainda segundo o mesmo registro, uma outra feição do Jornal começou a ser delineada, a partir do início da abertura política, quando houve uma espécie de explosão das camadas médias da população, até então sufocadas pelo fechamento político. Nesse momento, a Folha tratou de absorver rapidamente jornalistas da imprensa alternativa e, a partir daí, procurou lançar-se como o jornal da abertura. 
O empenho na campanha de 82, como simpatizante do PMDB, já significara um primeiro passo na sua afirmação política. Com a perspectiva das diretas-já, em 1984, Marcondes Filho lembra que a Folha entrou no movimento, após curta indecisão, para dele sair como o jornal dos novos tempos. Transformou-se em porta-bandeira do movimento, e, constatando a agregação de que passara a ser objeto, obteve, através dele, dividendos ideológicos e econômi$\cos$.

Poder-se-ia acrescentar que, após a derrota da emenda das eleições diretas, o Jornal prosseguiu na defesa da normalidade democrática, assumindo uma atitude fiscalizadora junto a governantes de todos os níveis, o que permitiu classificá-lo, no período abrangido pelo "corpus", como um veículo de oposição ao governo.

Além dessa preocupação, a Folha defende a preservação dos direitos humanos, a livre iniciativa, o direito à propriedade, a forma representativa de governo, a pluralidade de idéias, e procura analisar em profundidade quaisquer fatos político-sociais que possam interferir na vida dos brasileiros.

\section{O Jornal e o público-alvo: imagens recíprocas}

A idéia que a Folha faz de seu alocutário-padrão é a de um leitor mais escolarizado que a média dos brasileiros e interessado não só em notícias, mas também numa análise mais cuidadosa dos fatos e no aprofundamento de matérias referentes a um abrangente leque de atividades profissionais e socioculturais abordadas pelo Jornal. Embora não seja explicitada, essa imagem pode ser depreendida pelo próprio esquema de estruturação do Jornal e pela comparação da Folha de São Paulo com os outros dois diários editados pela empresa Folha da Manhã: Notícias Populares e Folha da Tarde, dirigidos a públicos diferentes.

O primeiro, Notícias Populares, apresenta uma linguagem notoriamente marcada por valores expressivo-apelativos e se dirige às classes mais populares. Busca, mais que noticiar fatos, posicionar-se explicitamente, através de um alto índice de adjetivos, vocativos e manchetes chamativas, propositadamente carregadas de ambigüidade. A própria escolha dos assuntos é marcadamente direcionada para a violência, para o sexo, para a busca da exceção, narrada com riqueza de detalhes sensacionalistas, pretendendo cativar um determinado tipo de leitor e levá-lo a comprar o periódico, com certa assiduidade. 
Por sua vez, o jornal Folha da Tarde, segundo Faria (1991), equaciona as funções referencial e expressiva, e é dirigido a uma classe média "sem grandes pretensões intelectuais", que deseja, principalmente, ser informada sobre os principais acontecimentos do dia.

Os motivos que, segundo Hohenberg (1962), levam as pessoas a ler jornais são busca de informação, prazer, instrução, curiosidade e, ocasionalmente, até mesmo um sentimento de respeito à liderança exercida pelo veículo. Certamente, cada um desses aspectos pode levar alguém a ler um jornal pela primeira vez. Entretanto, provavelmente, o leitor mais exigente não voltará a fazê-lo se não encontrar seriedade no veículo, se não conseguir identificar claramente sua postura ideológica, se não detectar, pelo menos na maioria das vezes, um distanciamento crítico em relação aos assuntos tratados, se não perceber consistência nas análises, enfim, se não sentir no jornal uma preocupação com a exatidão das informações que inspire credibilidade. Parece ser exatamente esse leitor mais exigente que a Folha de São Paulo pretende atingir.

As imagens que movem o alocutário podem ser confirmadas a partir de uma leitura atenta do Painel do Leitor (p.1-3) e da coluna dominical do Ombudsman, que refletem as reações e opiniões de uma representativa parcela dos leitores do Jornal. Nessa seção, os leitores avaliam, igualmente, certas decisões da Folha. Por exemplo, em relação ao corte da coluna de um jornalista que havia se encontrado com o presidente Collor, sem comunicar ao Jornal, os leitores dividiram-se, mas a maioria posicionou-se contrariamente à punição, numa demonstração de apreço à independência e repulsa ao autoritarismo.

Merecem nota, igualmente, por serem o reflexo dos valores pessoais do leitor da Folha, as reações contra os juízos ou preconceitos contidos em determinadas criações ou escolhas vocabulares como o termo "ecochato", empregado por Ricardo Semler, em sua coluna dominical, para referir-se aos ecologistas, e a palavra "galinha", como sinônimo de mulher, em oposição a galã, empregada por José Simão, na coluna de televisão. Assumindo uma postura de defesa nacionalista em relação à língua nativa, os leitores reclamaram, ainda, da grande incidência, no Jornal, de vocábulos da língua inglesa ou dela derivados, como o caso do então recém-criado caderno para adolescentes, intitulado Folhateen.

Em cartas enviadas à Coluna do Ombudsman e ao Painel do leitor, os leitores contestaram informações, protestaram contra a exploração de apenas um lado da notícia, ou contra determinado crítico. Registraram também seus protestos contra declarações ou atitudes de algumas autoridades. Nesse sentido, a afirmação de Collor de que tinha "aquilo roxo" foi a que despertou maior 
indignação, tendo sido considerada inoportuna e vulgar. Um leitor, citando Rui Barbosa, afirmou que homem verdadeiro é aquele que tem autodomínio, que não se descontrola nos momentos difíceis. Outro, recorrendo à ironia, escreveu que, em vez de ficar se gabando de ter "aquilo" roxo, seria melhor que o presidente usasse "aquela" cinzenta.

$\mathrm{Na}$ opinião de alguns leitores, o Jornal radicaliza suas posições, principalmente frente ao governo federal, colocando-se, sistematicamente, contra todas as medidas anunciadas, postura atribuída a um "amor à discordância" ou desejo de "demonstrar força". A maioria, no entanto, considera "intrépida" a atuação do Jornal frente ao "mau comportamento" do Executivo.

O leitor espera encontrar no veículo de comunicação por ele escolhido pensamentos coincidentes com os seus, opiniões que reflitam, fundamentalmente, sua própria opinião a respeito dos fatos. Assim, apesar da permanente tensão entre a expectativa de ter um jornal objetivo mas ao mesmo tempo crítico e com posições de vanguarda, o leitor da Folha de São Paulo aparenta estar satisfeito e identificado com o periódico pelo qual optou.

\section{Objeto da matéria jornalística: momento histórico abrangido pelo "corpus"}

O momento histórico compreendido pelo "corpus" é outro aspecto importante a ser considerado. De março a julho de 1991, a imprensa noticiava e posicionava-se diante de fatos marcantes como, por exemplo, a substituição da ministra Zélia Cardoso de Melo, na Economia, pelo ministro Marcílio Marques Moreira. O fato teve grande Repercussão, dada a importância desse Ministério na vida dos brasileiros. A ministra havia interferido profundamente na economia do país, como um todo, e na de cada cidadão, em particular, dos quais bloqueara temporariamente as contas bancárias.

Pouco antes de seu afastamento, Zélia chegara à conclusão de que os padrões de inflação do primeiro mundo seriam inexeqüíveis no Brasil, a curto prazo, o que impossibilitava o cumprimento de promessas feitas pelo Presidente da República durante a campanha eleitoral e no início de seu governo.

A equipe econômica procurava controlar a inflação artificialmente, através de um congelamento de preços e salários, que provocava profundas distorções. A saída desse congelamento, segundo a Folha de São Paulo, deveria ser cuidadosa, pois do contrário poderia "implicar tensões perigosamente explosivas ou conseqüências nefastas sobre a situação inflacionária". Zélia 
Cardoso de Melo, entretanto, afirmava que o controle de preços viera "para ficar", num reflexo do "vício" ou da "obsessão" intervencionista, que o Jornal condenava. Ao lado disso, o cálculo da cesta básica, utilizado para medir o índice inflacionário, sofria expurgos de itens importantes como transporte e aluguel, e a moeda brasileira se desvalorizava continuamente.

O Jornal registrou, em alguns momentos, sinais de recuperação da economia como a elevação do nível de empregos, em São Paulo. Entretanto, quase três meses após o plano Collor 2, a equipe econômica apresentava sinais de desunião e proliferavam as ações judiciais visando ao desbloqueio de cruzados. Surgiram, nessa época, especulações sobre a substituição da ministra Zélia Cardoso de Melo por Eduardo Teixeira, fato que não se concretizou. Pouco depois, entretanto, a ministra teve um atrito com o secretário de Desenvolvimento Regional, Egberto Batista, devido à revogação feita por ela de uma portaria do secretário que dava à Superintendência da Zona Franca de Manaus autonomia para liberar guias de importação de matéria-prima e componentes destinados a empresas instaladas na Zona Franca. Tal portaria, segundo informações "vazadas" por assessores da ministra, visaria a beneficiar o irmão do secretário, Gilberto Batista, um suplente a senador com negócios em Manaus. Sob a ótica do secretário, a revogação feita por Zélia devia-se à influência do ex-ministro Bernardo Cabral, outro amazonense com interesses na Zona Franca e com o qual a ministra mantinha um romance "proibido". Egberto Batista era figura importante daquilo que o Jornal denominava "República de Alagoas" e, esse fato, somado ao crescimento da inflação e à recessão em que se encontrava o país, bem como ao desejo de mudar a imagem desgastada do governo, ocasionou a queda da ministra Zélia Cardoso de Melo.

Em seu lugar, assumiu o diplomata Marcílio Marques Moreira. O Jornal registrou, na época, a mudança de ânimo dos brasileiros, ocasionada pela troca de ministro. Alertou, porém, para a maior existência de dúvidas do que de certezas quanto a seu desempenho, uma vez que o problema do país não estava exatamente no ministro, mas se encontrava "mais em cima".

Diante da nomeação do novo ministro, a primeira reação dos empresários, segundo o Jornal, foi de desconfiança. Para eles, Marcílio não seria suficientemente duro para enfrentar pressões e vencer os desafios impostos pela indefinição da economia. O governo encontrava-se, naquele momento, ante o desafio de defender um programa antiinflacionário aliado à expansão da economia. O congelamento de preços vigente não poderia se perpetuar, havia um notável desequilíbrio nas contas públicas, o índice de desemprego era alto e havia sido detectada até mesmo uma significativa diminuição no consumo de 
feijão no país. Conforme afirmação do ministro, pouco tempo após assumir sua pasta, o Brasil havia chegado ao fundo do poço.

A Central Única dos Trabalhadores, CUT, em sinal de protesto contra a situação, chegou a convocar uma greve geral, ignorada pelo governo, e por, praticamente, toda a população. Nem mesmo os metalúrgicos do $\mathrm{ABC}$, berço da CUT, participaram do movimento. Essa ausência foi creditada pelo Jornal à falta de alternativas políticas. Na verdade, segundo a Folha, a CUT encontravase "tão perdida quanto o presidente". Após a frustração do movimento paredista, surgiram discussões de avaliação sobre o futuro da cuT e do Partido dos Trabalhadores.

Apesar de todas as dúvidas sobre seu sucesso no cargo, o ministro Marcílio Marques Moreira representava, nas palavras de Otto Lara Rezende, "um calmante oportuno". Com ele, inaugurou-se no governo o chamado "estilo soft", baseado no entendimento, no diálogo.

A nova equipe econômica contava com vários ex-integrantes do governo José Sarney e, devido à desarticulação entre seus membros, foi comparada pelo Jornal à problemática seleção brasileira de futebol, na época dirigida por Paulo Roberto Falcão. Entretanto, apesar dos desencontros, essa equipe foi responsável por um certo acomodamento psicológico no país, já que sua grande novidade, segundo o empresário Emerson Kapaz, era "o fato de não produzir novidades". Mas, o realinhamento de preços por ela efetuado transmitiu, conforme o Jornal, um clima de esperança aos empresários do setor industrial, especialmente. Esse clima de conciliação foi rompido no início de julho por uma Medida Provisória, considerada pelos empresários um casuísmo oficial, que antecipava o recolhimento do imposto sobre produtos industrializados, o que, na prática, representava um aumento de custos de até $10 \%$ ao mês.

$\mathrm{Na}$ área política, era o presidente da República a figura mais comentada. O Jornal destacava o não cumprimento das promessas de campanha, chamando-o de Pinóquio; enfatizava também seu esforço em conseguir apoio da mesma classe política que, antes da eleição, afirmara desprezar. Para o Jornal, por trás da retórica que glorificava o diálogo, o presidente tratava de ressuscitar o velho método de trocar recursos públicos por apoio político, enquanto a recessão campeava.

A população demonstrava apreensão. No dia 22 de março, chegou a haver o que o Jornal chamou de "tentativa de ameaça" à vida do presidente por um cidadão desempregado já havia dez meses, durante a cerimônia de descida da rampa do Planalto. Ao ser preso, portando uma faca de cozinha, o rapaz afirmou desejar apenas assustar o presidente. 
Este, que assumira o governo com uma aura salvacionista, como aquele que representava a solução, a curto prazo, de todos os problemas do país e a sua inserção no primeiro mundo, passou a revelar toda a sua "instabilidade emocional", sua "imaturidade" e seu "temperamento explosivo". Era o que se podia concluir, segundo o Jornal, de atitudes como o gesto obsceno que fizera em cima de um palanque, ou o discurso inflamado em que reafirmara sua virilidade, numa tentativa de intimidar manifestantes insatisfeitos com seu governo.

Num segundo momento, o da fase "soft", o presidente passou a buscar atrair para o governo personalidades de certa respeitabilidade e notoriedade social. Concedeu também entrevistas, explicando seu temperamento, assumindo sua face explosiva, mas afirmando possuir uma outra face, "mais terna", e, num desabafo, atribuiu a grupos organizados a tentativa de impedir o desenvolvimento do país. Finalmente, derramou furtivas lágrimas, ao assistir à apresentação de um coral de crianças pobres no Palácio do Planalto. A Folha de São Paulo ironizou o fato, afirmando que essas lágrimas não teriam sua autenticidade investigada, como ocorrera dias antes com as "lágrimas" de uma imagem de Nossa Senhora da Rosa Mística, a Virgem de Louveira. (Parece que a mudança de estilo surtiu efeito, pois, no dia 30 de junho, o Jornal publicou o resultado de uma pesquisa de opinião que registrava uma melhoria nos índices de popularidade de Collor).

Também a imagem de "antimarajá", construída pelo presidente durante a campanha, foi questionada pelo Jornal. Era incompatível com essa imagem a manutenção no poder do ministro do Trabalho e Previdência Social, Antônio Rogério Magri, figura folclórica que acumulava, ilegalmente, dois cargos públicos (o de ministro e outro na Eletropaulo, companhia subordinada à Secretaria de Energia e Saneamento do Estado de São Paulo), e era, na verdade, um "ministro sem pasta", já que não dirigia, de fato, o Ministério. Além disso, utilizara carros oficiais para levar animais de estimação ao veterinário e abandonara uma reunião da Organização Internacional do Trabalho, realizada na Suíça, para fazer compras. Ao tentar assumir efetivamente as funções inerentes ao seu posto, tornou ainda mais complexa sua situação, apresentando ao país uma lista equivocada daqueles que seriam os "marajás da previdência". Esse equívoco, as fraudes na Previdência Social e a sugestão de uma auditoria para apurá-las, as declarações e contradeclarações do procurador geral do INSS, tudo isso, somado às idiossincrasias do ministro, levava os órgãos de imprensa a freqüentemente preverem sua saída, fato que não ocorreu durante o período aqui tratado. 
Outras falhas cometidas pelo governo ou irregularidades perante as quais ele se revelara omisso foram noticiadas na época. Pode-se incluir aqui a operação de socorro aos usineiros; a carta de Belo Horizonte, que denunciava negociações ilícitas entre empreiteiros e governo; o caso do café, segundo o qual pessoas ligadas à ministra Zélia Cardoso de Melo teriam tido acesso a uma informação privilegiada sobre medidas que seriam tomadas com relação à exportação de café; irregularidades na Central de Medicamentos; irregularidades na Legião Brasileira de Assistência, dirigida pela primeira dama do país; e os contratos de publicidade firmados pelo governo, sem licitação. A divulgação de todos esses fatos e mais a "fogueira de nulidades" que constituía o ministério Collor contribuíam para desgastar a imagem do presidente, afetando seriamente sua credibilidade.

Também o Poder Legislativo acumulava desencontros. No mês de março, protagonizou um cômico episódio, quando do desentendimento gerado pela disputa do patrocínio do "Fórum de Entendimento Nacional". A disputa, além dos partidos entre si, cada qual buscando liderar o referido fórum, envolvia também o Palácio do Planalto. Sobre esse "Fórum de Entendimento Nacional", Gilberto Dimenstein chegou a afirmar que o único consenso era a ausência de consenso.

$\mathrm{Na}$ área da saúde, ocorria o início da epidemia de cólera no país, graças à inércia governamental, que não priorizara sua prevenção. Segundo o Jornal, esta teria sido, entretanto, muito difícil, pois dependia de saneamento básico, algo extremamente precário no Brasil, conforme dados divulgados pelo IBGE. A Folha denominava, assim, o alastramento da doença de "epidemia de descaso".

Quanto à educação, o projeto "Minha Gente", que previa a "construção de cinco mil vistosos centros de ensino em prazo meteórico", encontrava-se na ordem do dia. Conforme palavras do titular do Ministério da Criança, Alceni Guerra, o critério para a instalação desses CIACs era "politico", forma de distribuição condenada pelo Jornal, que defendia uma orientação por requisitos técnicos e exigências sociais, que não visasse atender apenas às conveniências do governo.

A polêmica envolvendo os CIACs abrangia discussões sobre os processos de licitação para sua construção, os efeitos eleitorais que estariam por trás deles, e a sua utilização como material publicitário para uma possível reeleição de Collor. Apesar de alertar para a existência de todos esses riscos, o Jornal considerava um avanço a decisão de colocar o ensino básico como prioridade. 
Quanto aos temas de interesse nacional, o Jornal defendia a necessidade de uma reforma tributária urgente e a antecipação da devolução dos cruzados novos bloqueados. Posicionava-se contrariamente à legalização dos cassinos no país, diferentemente da maioria dos congressistas, que mostrava disposição em apoiá-la. Opunha-se, também, radicalmente, à pena de morte, levantando, inclusive, a questão da impropriedade da realização de um plebiscito sobre o assunto, conforme havia proposto ao Congresso o deputado Amaral Netto.

Tendo em vista a dolarização da economia argentina, discutia-se a viabilização dessa estratégia também na economia brasileira, com base no dito popular segundo o qual tudo o que acontece na Argentina, mais cedo ou mais tarde, acontece também no Brasil.

Esses eram, em síntese, os temas noticiados e comentados pelo Jornal, num momento histórico particularmente importante para o país.

\section{A teoria e a prática nos textos do caderno "brasil"}

É fundamental, para a produção da leitura, a abordagem das características tipológicas dos textos em análise. Assim, serão caracterizados, a seguir, os diferentes textos jornalísticos que compõem o primeiro caderno, segundo suas finalidades e princípios de formação.

Os textos que fundamentalmente constituem um jornal são as notícias que, segundo o NMR, se constituem em mercadorias a serem tratadas com rigor técnico (p. 13). O Manual considera notícia: "o fato comprovado, relevante e novo" (p. 27), isto é: o fato que pode gerar maiores conseqüências para o mundo, para a sociedade e para os leitores; o fato que desperta curiosidade, ou aquele que é objeto de maior identificação entre o público leitor e a personagem ou a situação do ocorrido; o fato mais inesperado e aquele que os poderosos têm interesse em ocultar. Dessa forma, segundo o NMR (p. 35), são critérios elementares para definir a importância da notícia o ineditismo, a improbabilidade, o apelo, o interesse e a empatia.

$\mathrm{O}$ caráter impessoal atribuído à notícia nos meios de comunicação atuais, é, segundo o autor, apenas aparente. Na verdade, ela pode não refletir as crenças e perspectivas do indivíduo, como ocorria em um momento histórico anterior, mas, certamente, reflete as crenças e perspectivas da coletividade que a produz. Para ele, a melhor técnica apenas oculta preconceitos e pontos de vista do grupo social dominante. 
Nessa mesma direção, Marcondes Filho (1986) recusa à notícia a função referencial pura, por considerar impossível a objetividade plena, já que "a possibilidade de possuir a verdade é falsa e tende ao discurso dogmático" (p. 14). Segundo ele:

Notícia é a informação transformada em mercadoria com todos os seus apelos estéticos, emocionais e sensacionais; para isso a informação sofre um tratamento que a adapta às normas mercadológicas de generalização, padronização, simplificação e negação do subjetivismo. Além do mais, ela é um meio de manipulação ideológica de grupos de poder social e uma forma de poder político. (p. 12)

Na visão do NMR, a inexistência de uma objetividade pura em jornalismo deve-se ao fato de que a própria escolha de um assunto, a redação de um texto e sua edição implicam tomada de atitudes bastante subjetivas, influenciadas pelas posições pessoais, hábitos e emoções do jornalista. Esse aspecto é também acentuado por Van Dijk (1989), que lembra, ainda, que a própria produção de notícias consiste, em grande medida, numa forma de processamento do texto, já que, freqüentemente, o repórter toma conhecimento dos acontecimentos através de outros tipos de discurso, os chamados "textos-fonte", constituídos por informes de outros meios, mensagens transmitidas por telefax, boletins de imprensa, documentos, publicações, conversações telefônicas, entrevistas, etc. Além disso, os próprios acontecimentos das notícias são, muitas vezes, de natureza textual, tais como declarações de autoridades, debates no congresso, negociações, cartas, ou outras formas de discurso público envolvendo pessoas, organizações ou países.

Evidentemente, em cada fase dessa cadeia textual, os acontecimentos são codificados e recodificados, sendo-lhes incorporadas as cognições de cada locutor ou instituição. No trecho noticioso abaixo, por exemplo, ao empregar o verbo admitir, o jornalista enfatiza sua percepção da relutância do personagem da notícia em reconhecer uma situação que, segundo ele, já era do conhecimento de toda a opinião pública: o fracasso da reforma agrária brasileira. 
Cabrera admite fracasso da reforma agrária.

O ministro da Agricultura, Antônio Cabrera, admite que a estrutura para a reforma agrária implantada pelo governo Collor falhou. "A tentativa não foi boa. Acabou burocratizando o processo", disse o ministro. (13/3 p. 1-5)

Em outro momento, uma notícia lança mão da ironia ao relatar uma declaração feita pelo ministro da Aeronáutica, Sócrates Monteiro, ao repórter Eumano Silva, em abril de 1991. Nessa época, os militares reivindicavam melhores salários, argumentando que a má remuneração poderia colocar em risco a "segurança da pátria", já que os problemas financeiros não lhes dariam a tranqüilidade necessária para bem desempenhar suas atividades. Uma declaração com esse conteúdo, foi feita pelo ministro, após condecorar com a Ordem do Mérito Aeronáutico a ministra da Economia, Zélia Cardoso de Mello, principal responsável por um possível reajuste salarial. Questionado a esse respeito, o ministro, obviamente, negou qualquer relação entre a condecoração e as reivindicações dos militares. O repórter marca, então, seu descrédito na declaração, através da seguinte manchete com conotação irônico-humorística, baseada na exploração de um fragmento de citação da fala do ministro, dada no corpo da notícia:

Medalha a Zélia "foi coincidência"

$(24 / 4$, p. $1-4)$

Outra modalidade textual presente no "corpus" de análise é a reportagem que, diferentemente da notícia, trata de assuntos, não necessariamente de fatos novos. Ou seja, os assuntos para reportagem estão sempre disponíveis e podem ou não ser atualizados por um acontecimento (cf. Lage, 1985a). O ângulo sob o qual o levantamento do assunto deve ser realizado na reportagem é preestabelecido pela diretriz do jornal.

Pode ilustrar essa modalidade textual uma matéria de página inteira apresentada pelo jornal em 20 de março, sob a denominação de Caos urbano, enfocando vários dos efeitos das enchentes que atingiram a cidade de São Paulo naquele mês: o maior congestionamento dos nove anos precedentes, 
morte de um motorista, corte de luz, de telefone e de gás canalizado, inundação de casas (mesmo as da classe média) e outros transtornos variados, para pessoas que residiam ou se encontravam na cidade. Essa foi a primeira de uma série de reportagens sobre o mesmo tema, enfocando as causas do caos, buscando os políticos estaduais ou municipais responsáveis pela situação e procurando prevenir acontecimentos semelhantes.

Apresenta-se igualmente no "corpus" uma outra modalidade de matéria noticiosa: a entrevista que, sob a forma de perguntas e respostas pode pretender, segundo Lage (1985a), tentar extrair do entrevistado informações que resultarão em notícia (entrevista noticiosa), levantar a opinião sobre o assunto pesquisado (entrevista de opinião), ou levantar aspectos biográficos do entrevistado (entrevista de ilustração).

O primeiro caderno da Folha de São Paulo prioriza as entrevistas noticiosas, vindo em segundo lugar as de opinião; as de ilustração, quando ocorrem, confundem-se com as noticiosas, isto é, falam da vida de personagens que de alguma forma têm ou já tiveram alguma relevância perante o público, e, por isso, são notícia. É o caso da longa entrevista feita com Miriam Cordeiro, ex-namorada do então deputado Luís Inácio Lula da Silva, no dia 9 de junho, próximo ao dia dos namorados. A entrevistada era conhecida dos leitores, por haver dado um contundente depoimento, às vésperas das eleições de 1989, afirmando que Lula, candidato à Presidência, teria the pedido para fazer um aborto, quinze anos antes. Após a aparição no programa político de Fernando Collor, o que certamente contribuiu para a derrota de Lula nas eleições, quase nada se havia falado a respeito de Miriam, até o Jornal publicar a entrevista de mais de uma página, sob o título Namoro e ódio: Ex-namorada de Lula diz que não se arrepende. Na entrevista, ela falou de seu passado ao lado de Lula, de seu depoimento na campanha presidencial, de seus planos para o futuro, assumiu-se como "marajá", uma vez que vivia confortavelmente, sustentada por "pessoas simpatizantes do presidente Collor", e afirmou que faria tudo "de novo e melhor".

Uma outra modalidade textual específica é a chamada de primeira página do jornal, que se propõe a orientar a visão do leitor, através da condensação de grandes quantidades de informação, da seleção e da supressão de dados e, especialmente, da hierarquização dos acontecimentos. Por sua natureza heterogênea, a primeira página tem um papel fundamental na composição da imagem da realidade pelos leitores. Tanto isso é verdade que, como lembra Suzuki Júnior (1985), quando se quer dar uma idéia do que ocorreu em um determiado momento, é comum se reproduzir somente a capa de um grande jornal. 
Seu texto exige frases curtas, secas, substantivas, que dêem ao leitor uma idéia de completude, mas, ao mesmo tempo, o remetam para as páginas que trazem a cobertura extensiva, numa premeditada intertextualidade, interna à edição de cada número do jornal.

Cabe lembrar aqui uma chamada de primeira página, referente ao então governador do Rio de Janeiro, Leonel Brizola, com quem, no momento analisado, o presidente Collor trocava favores. Para evidenciar essa situação, o Jornal utiliza-se do já comum desvirtuamento das palavras de São Francisco de Assis "É dando que se recebe", conferindo-lhe um significado novo, irônico e cômico. Da mesma forma, para relatar a reação verbal de Brizola, quando abordado sobre o assunto, reproduz o dito popular "Quem não chora não mama". O registro de tais estereótipos, além de provocar a adesão automática do leitor, garante rendimento comunicativo eficaz: sendo o seu significado corrente conhecido de todos os leitores, a compreensão do significado cômico-irônico de toda a situação ali resumida é imediata:

ESTILO SOFT ABRE CORRIDA AOS COFRES Na nova versão do "é dando que se recebe", Brizola diz que "quem não chora não mama". (26/05, p. 1-1)

Um jornal não se faz apenas de notícias e reportagens: sua opinião explícita é também objeto de consumo e uma das razões que conduzem o leitor na escolha do periódico de sua preferência. Na modalidade textual opinativa incluem-se os editoriais, que representam a opinião oficial do jornal, e os artigos assinados, que podem seguir ou não a linha do periódico.

Marcelo Coelho, num artigo publicado na própria Folha de São Paulo em 24/04/92, em que comenta o lançamento do livro Meninas da Noite, de Gilberto Dimenstein, afirma que os editoriais de jornal estabelecem um contraponto inevitável com a crueza das reportagens: enquanto a notícia apresenta secamente os fatos, de forma irresolvida e material, o editorial comenta, posiciona-se, contesta, interferindo sobre as pequenas doses de absurdo apresentadas aos leitores todos os dias. Para ele, é como se, enquanto a manchete dissesse: "foi isso!", o editorial respondesse: "mas não pode ser!". Dessa forma, segundo o autor, o editorial do jornal estabelece uma relação particular com a transitividade dos fatos, representando um apelo para que as coisas mudem, para que não se resumam a ser simplesmente o que são. 
Para ilustrar essa modalidade textual, pode-se citar o editorial Desperdício Publicitário, de 08/05/91. No texto, ao comentar a utilização de uma campanha publicitária com o objetivo de melhorar a imagem do governo federal, o jornal condena a autopromoção pretendida pelo governante, em substituição a uma possível reflexão sobre as deficiências da atuação oficial, menciona o preço da campanha (Cz\$ 900 milhões), e ironiza a interpretação dada à atuação da imprensa:

Conforme a fértil imaginação do publicitário, haveria oculto um Brasil em franco desenvolvimento, resplandecente, que a população, lamentavelmente, ainda desconhece.

Emprega, ainda, o verbo alegar para marcar o distanciamento crítico de oposição do jornalista ao que diz o locutor citado. Segundo o NMR, alegar é "o verbo do réu", contendo em si a idéia de explicação, desculpa ou justificativa diante de uma situação qualquer. Trata-se de um verbo tipicamente polifônico, já que pressupõe o acúmulo de duas vozes como que informando ao leitor: $a$ ) fulano justifica-se, dizendo que...; b) eu não acredito na justificativa apresentada. Além disso, a frase com que o jornalista inicia o parágrafo retrata claramente sua dissonância e indignação perante a atitude de descaso do locutor citado para com a inteligência da sociedade:

Fazendo pouco caso da capacidade de discernimento da sociedade, o dirigente da agência encarregada da campanha alega que é preciso atacar a onda pessimista.

Ao final, confirmando a inutilidade da milionária campanha, o texto conclui:

$\mathrm{Na}$ verdade, se alguma serventia terá a campanha será a de reafirmar um postulado implacável da publicidade - a de que não há propaganda capaz de transformar um mau produto em seu inverso. 
A presença do jornalista no texto pode ser percebida até mesmo na seção Frases, constituída por uma coletânea de frases de impacto, proferidas por personalidades em evidência. Essa seção subdivide-se em De hoje e De ontem, e pode abordar posições contraditórias de um mesmo locutor a respeito de um tema, em momentos distintos, comportando, nesse caso, lances de discreta ironia; pode também pretender cotejar posições de locutores distintos sobre assuntos polêmicos; pode recortar, ainda, declarações originais ou humorísticas, as quais, seja pela sua forma, seja pelo seu conteúdo, são capazes de provocar um certo impacto.

Assim, embora não haja nenhum comentário explícito sobre as frases, apenas a sua citação, com a informação do autor, da data e do contexto em que foi proferida, o locutor acaba por tecer, através de citações, um texto integral, que atinge coerência pela unidade semântica estabelecida no confronto entre elas.

Sirvam de amostragem, aqui, as considerações, em linhas opostas, feitas por dois adversários políticos, Collor e Lula, a respeito do futuro do país, confrontadas com a afirmação anterior de um outro político, o deputado Roberto Campos, para quem no Brasil tudo pode acontecer :

\author{
De hoje \\ "Acreditamos sempre no Brasil, rumo à retomada do desenvol- \\ vimento com justiça social." (Presidente Fernando Collor de \\ Mello, na Folha) \\ "Aí não adianta discutir quem está na primeira classe. A briga \\ maior de todo mundo é fazer o trem andar." (Luís Inácio Lula \\ da Silva, presidente do PT, comparando o país a um trem para- \\ do no deserto, na Folha) \\ De ontem \\ "No Brasil, só há uma coisa realmente impossível: o possível." \\ (Roberto Campos, deputado federal pelo PDS-RJ, em 21/ \\ 03/91) $(29 / 05$, p. 1-2)
}

Também interessante para a presente análise é o Painel, constituído de pequenas notas sobre os bastidores da política, cada uma delas com um título bastante sugestivo. Há dentro do Painel duas outras subseções: Tiroteio e Contraponto. A primeira geralmente relata a declaração inusitada de uma per- 
sonagem da política nacional a respeito de um opositor ou de um fato adverso. A segunda narra, em tom humorístico, um episódio inédito, recente ou não, envolvendo figuras do cenário político. Lembrando Bakhtin (1979), para quem toda citação traz implícito um comentário, seguem, a título de ilustração duas citações de Tiroteio, que focalizam as divergências entre adversários políticos famosos:

\section{TIROTEIO}

Do presidente do PMDB, Orestes Quércia, sobre o governo do presidente Collor:

- O governo Collor vai muito mal. O pessoal que está tomando conta não é do ramo. Quando aprender, acaba o mandato. (08/ 05/91)

Do senador Fernando Henrique Cardoso (PSDB-SP), no programa "Roda Viva", sobre o índice de 50\% de ótimo/bom obtido por Quércia na mais recente pesquisa do DataFolha: -Parece que o crime compensa. (13/03/91)

Já o Contraponto abaixo ironiza as dificuldades enfrentadas pelo governo federal, insinuando que a solução dos problemas nacionais só seria possível através de ampla interseção e amparo divinos:

\section{CONTRAPONTO EM QUANTIDADE}

O deputado federal Euclydes de Melo (PRN-SP), primo do presidente da República, esteve há dez dias em São Simão, no norte paulista, a $285 \mathrm{~km}$ da capital, para participar da inauguração de uma agência da Caixa Econômica Federal. O parlamentar discursou na cerimônia, ao lado do prefeito, padre Plínio Toldo (PFL): 
- Padre, eu vou levá-lo a Brasília para que o senhor abençoe o meu gabinete, o da ministra Margarida Procópio e o do presidente da Caixa, Lafaiete Coutinho.

O padre não se conteve:

- E o do presidente também.

Melo concordou:

- E o do presidente também.

Encerrada a solenidade, o deputado virou-se para o prefeito:

- Padre, como eu sei que o senhor é pobre, vou mandar uma passagem de avião até Brasília.

- Não se preocupe, meu filho, eu vou na boléia do caminhão.

- Que caminhão, padre?

- O caminhão que vai levar toda essa água benta. (13/03/91)

\section{Conclusão}

Pôde-se perceber no decorrer da análise que, ao contrário do que prega, em tese, o Novo Manual de Redação da Folha de São Paulo, a manifestação de opinião não se circunscreve às colunas e aos artigos, o tom dos textos noticiosos nem sempre é sóbrio e descritivo, e a ironia não se apresenta apenas em textos assinados ou em colunas de bastidores. A avaliação do locutor está sem- 
pre presente, não apenas nos textos com função comentadora, em que não haveria motivo para mascaramento de opiniões.

Considerando que a informação veiculada pelo jornal é um fato discursivo indicador de seu posicionamento ante os acontecimentos, a "verdade" dos textos jornalísticos deve ser buscada não apenas na concordância entre o narrado e o ocorrido, mas também na seleção e ordenação de vocábulos, acontecimentos e declarações, nas lacunas deixadas entre as informações e nas indicações sugeridas sobre a forma de preenchê-las. Essa constatação é sintetizada por Marcelo Leite, ex-ombudsman da Folha de São Paulo, para quem "a distinção entre notícia e opinião é fundamental para se entender um jornal, mas às vezes a mistura das duas coisas permite compreendê-lo ainda melhor". (Marcelo Leite, ex-ombudsman da Folha de São Paulo).

\section{RESUMO}

O trabalho focaliza a construção da realidade feita, através do discurso jornalístico, pela Folha de São Paulo, jornal cuja auto-imagem é a de um veículo de comunicação crítico, apartidário, pluralista e independente. Por sua vez, a imagem do leitor a respeito do Jornal, durante o período investigado (março a julho de 1991), é a de um veículo de postura ideológica nitidamente anti-governista, embora com capacidade de distanciamento crítico e preocupação com a exatidão das informações. O "corpus" analisado retrata um momento de importância decisiva na história recente do Brasil: o início da veiculação dos episódios que culminariam no "impeachment" do presidente da República, Fernando Collor de Mello. Pode-se constatar, após um pequeno distanciamento temporal, que o jornal fez mais do que narrar e comentar os fatos: foi um dos responsáveis pelo seu desfecho.

Palavras-chave: Discurso jornalístico, realidade discursiva, objetividade jornalística. 


\section{ABSTRACT}

This article focuses on how journalistic discourse constructs reality through the text rather than by referring to the world. In the case of Folha de S.Paulo, this process is performed in a subtle way, to preserve its self-image as a critical, unbiased, pluralist and independent medium of communication. On the other hand, at least during the period investigated, the reader's view of this newspaper was that of an antigovernment newspaper though keeping critical distance and accuracy of infomation intact. The corpus analyzed focuses on a crucial moment in Brazil's recent history: the initial disclosure of the episodes that culminated in President Collor's impeachment. Even after a short lapse of time, it is possible to notice that this newspaper, in addition to reporting and commenting the facts, was one of agents responsible for the final outcome.

Key-words: Journalistic discourse, discursive reality, journalistic objectivity.

\section{REFERÊNCIAS}

BAKHTIN, M. (V. Voloshinov) (1929). Marxismo e filosofia da Linguagem. Tradução: M. Lahud e Y. F. Vieira. São Paulo: Hucitec, 1979. (Coleção Linguagem).

COELHO, M. "Meninas da Noite" sufoca pelo realismo (O livro de Gilberto Dimenstein sobre prostituição infantil nos deixa desesperados e atônitos). Folha de São Paulo, 29 abr. 1992. p. 4-8.

DUCROT, O. O dizer e o dito. Campinas: Pontes, 1984.

FARIA, M. A. O jornal na sala de aula. São Paulo: Contexto, 1991.

FOLHA DE SÃO PAULO. Caderno brasil, 13 mar.-14 jul. 1991.

HOHENBERG, J. Manual de jornalismo. Tradução: R. Jungmann. Rio de Janeiro: Fundo de Cultura, 1962.

LAGE, N. Ideologia e técnica da notícia. 2. ed. Petrópolis: Vozes, 1982.

. Linguagem jornalística. São Paulo: Ática, 1985a.

. Estrutura da notícia. São Paulo: Ática, 1985b. 
MARCONDES FILHO, C. O capital da notícia (jornalismo como produção social de segunda natureza). São Paulo: Ática, 1986. (Ensaios).

NOVO Manual da Redação. São Paulo: Folha de São Paulo, 1992 .

SEVCENKO, N. O rosto do Mundo. Folha de São Paulo, 1985. Primeira Página.

SUZUKI JUNIOR, M. A maquiagem do mundo. Folha de São Paulo, 1985. Primeira Página.

VAN DIJK, T. A. Estructuras y funciones del discurso. (Tradução Espanhola M. Gann e M. Mur) 6. ed. México: Siglo Veinteuno, 1989. 
